KS. MAREK ZABOROWSKI

\title{
DYSPENSA W PRAWODAWSTWIE KOŚCIELNYM
}

Treść: Wstęp. - 1. Pojęcie dyspensy,jej zakres i rodzaje. - 2. Władza dyspensowania. - 3. Przyczyna udzielania dyspensy. - Podsumowanie.

\section{Wstęp}

Każda ustawa ma na celu przede wszystkim dobro wspólne, a więc dobro ogółu. Jednak społeczność składa się z poszczególnych osób, dla których w konkretnym przypadku ustawa może okazać się zbyt uciążliwa, powodując szkodę lub przeszkadzając w osiągnięciu przez jednostkę większego dobra. Do zaradzenia tym kolizyjnym sytuacjom służy dyspensa ${ }^{1}$. Ma ona charakter normy korygującej w wypadkach, w których słuszność naturalna domaga się, aby kompetentna władza niejako zawiesiła na moment skuteczność ustawy².

W pierwszych wiekach chrześcijaństwa Kościół zmieniał lub łagodził przepisy w zależności od okoliczności. Rozluźnienie obowiązujących przepisów w poszczególnych przypadkach, w pierwotnym Kościele spotykamy najczęściej w celu ważnego i godziwego trwania tego, co pierwotnie było dokonane bezprawnie. $\mathrm{Z}$ czasem udzielano dyspens także przed dokonaniem czynności, pozwalając na to, co według przepisów kościelnych było zabronione ${ }^{3}$. Od IX wieku dyspensą nazywano każdy wyjątek od ustawy. „Dekret Gracjana” podał szeroką definicję dyspensy, której elementami są: rozluźnienie ustawy i spe-

\footnotetext{
${ }^{1}$ R. SoBAŃSKI, Kościót - prawo-zbawienie, Katowice 1979, s. 285.

2 Zob. F. BĄczkowicz, Prawo kanoniczne, t. I, Opole 1957, s. 262.

3 Tamże, s. 263.
} 
cjalne przyczyny tj. okazanie miłosierdzia i pożytek Kościoła (C.1, q. 7$, c. 23$)^{4}$.

Kodeks prawa kanonicznego z 1983 roku po raz pierwszy określił dyspensę jako konkretny akt administracyjny, a więc inaczej aniżeli poprzedni Kodeks, który utożsamiał ją z aktem ustawodawczym ${ }^{5}$.

\section{Pojęcie dyspensy, jej zakres i rodzaje}

Słowo dyspensa pochodzi od łacińskiego słowa dispensatio, które w sensie właściwym oznacza dokładny podział (zwłaszcza na równe części), zarząd lub zagospodarowanie ${ }^{6}$. W tej treści kryje się także inne znaczenie, mianowicie dobre kierownictwo i zarządzanie, które domaga się umiejętnego łączenia surowości z łagodnością. Wyrazem dobrze pojętej łagodności ma być właśnie dyspensa, gdyż jest ona zwolnieniem od obowiązku zachowania konkretnego przepisu prawa w szczególnym przypadku i dla słusznej przyczyny. Zapewnia to prawu większą elastyczność, gdyż pozostaje samo w sobie nienaruszone, a osoby czy nawet cała społeczność, korzystając z dyspensy osiąga większe dobra duchowe? .

Dyspensę należy odróżnić od pozwolenia, indultu, absolucji, czy też przywileju.

Pozwolenie (licentia) jest bowiem aktem woli przełożonego kościelnego w formie zgody na dokonanie czynności, która bez tej zgody byłaby nieważna lub niegodziwa. Jest to więc przejaw zapobiegliwości i ostrożności prawodawcy. Dyspensa natomiast zawiesza skutki prawa

${ }^{4}$ J. Krukowski, Dyspensa, w: Komentarz do Kodeksu Prawa Kanonicznego, red. J. Krukowski, t. I, Poznań 2003, s. 149.

5 Tamże.

${ }^{6}$ Stownik kościelny łacińsko-polski, red. A. Jougan, Warszawa 1992, s. 203; dispensatio - 1. dokładny podział, 2. zarząd, zagospodarowanie, 3. urząd, zadanie, 4. rozporządzenie, 5. szczególne pozwolenie, zezwolenie, uwolnienie.

7 J. Grzywacz, Dyspensa, w: Encyklopedia Katolicka, t. IV, Lublin 1983, kol. 446; Zob. J. LEDERER, Der Diespensbegriff des kanonischen Rechts unter besonderer Berücksichtigung der Rechtsprach des CIC, München 1957, s. 59. 
w szczególnych przypadkach, np. w przypadku nieprawidłowości do święceń ${ }^{8}$.

Indultem (indultum), nazywa się udzielenie pozwolenia. Ma on charakter zbliżony do dyspensy, ale nią nie jest. Niektórzy uważają, że indult ma miejsce wówczas, gdy łaski udziela się na czas ograniczony. Absolucją (absolutnio) natomiast jest zwolnienie z obowiązku zachowania kary, a nie z obowiązku zachowania prawa9.

Przez przywilej (privilegium) rozumie się szczególny akt łaski, który zostaje udzielony dla pożytku osoby fizycznej lub prawnej. Kanoniści nazywają przywilej ustawą prywatną, bowiem udziela on łaski wbrew ustawie powszechnej lub partykularnej. Ewentualnie poza ustawą, czy też obok niej ${ }^{10}$. W znaczeniu szerszym przywilej niesie dla odbiorcy wyjątkowe uprawnienia. Natomiast dyspensa zawiesza tylko skutki prawa w poszczególnych przypadkach ${ }^{11}$.

Władza dyspensowania dotyczy ustaw nakazujących lub zakazujących. W wypadku ustaw nakazujących skutkiem negatywnym będzie opuszczenie czynności nakazanej przez prawo, zaś w przypadku ustawy zakazującej skutkiem negatywnym będzie wykonanie czynności zabronionej przez prawodawcę. Niezależnie od tego czy zakaz będzie obwarowany sankcją karną, czy też nie lub też, czy do zakazu dołączony jest skutek unieważniający czynność, bądź uniezdalniający osobę do jej wykonania ${ }^{12}$. Kościół nie zwykł dyspensować od niektórych ustaw kościelnych ze względu na ich powiązanie $\mathrm{z}$ wiarą i moralnością, czy też ze względu na ich istotne znaczenie dla utrzymania dyscypliny kościelnej ${ }^{13}$. Kościół nie może dyspensować w sensie ścisłym

${ }^{8}$ E. Eichmann, Lehrbuch des Kirchenrechts auf Grund des Codex Iuris Canonici, t. I, Paderborn 1934, s. 100.

9 J. GrzYwacz, Zakres biskupiej władzy dyspensowania, w: RTK 22 (1975) z. 5, s. 7.

${ }^{10} \mathrm{G}$. DzIERżon, Kontrowersje wokół definicji legalnej przywileju zawartej w kanonie 76 \$1 Kodeksu prawa kanonicznego z 1983 r, Annales Canonici 7 (2011), s. 102107.

${ }^{11}$ R. Strigl, Verwaltung und Verwaltungsverfahren, w: Grundis des nachkonziliaren Kirchenrechts, red. J. Listl, H. Müller, H. Schmitz, Regensburg 1999, s. s. 76.

${ }^{12}$ J. Miras, Poszczególne akty administracyjne. Dyspensy, w: Kodeks prawa kanonicznego - komentarz, red. P. Majer, Kraków 2011, s. 121-124.

${ }^{13}$ T. Pawluk, Prawo Kanoniczne wg Kodeksu Jana Pawła II, t. II, Olsztyn 1986, 
od prawa naturalnego lub prawa Bożego pozytywnego. Przedmiotem dyspensowania mogą więc być tylko normy prawne pochodzenia czysto kościelnego. Wyjątek stanowi dyspensa od małżeństwa zawartego, lecz nie dopełnionego (matrimonium ratum et non consummatum) oraz rozwiązanie małżeństwa na korzyść wiary (in favorem fidei), których może udzielić jedynie Biskup Rzymski na mocy władzy wikariusza Chrystusa (kan. 1698 KPK) ${ }^{14}$.

Powyższa zasada nie jest uniwersalna, gdyż ustawodawca wyraźnie spod przedmiotu dyspensowania wyłączył: ustawy karne i procesowe (kan. 87 KPK) oraz zespoły norm kanonicznych, którymi są ustawy kościelne, o ile definiują sprawy, które są istotnie konstytutywne dla instytucji i aktów prawnych (kan. 86 KPK). Spod władzy dyspensowania są więc wyłączone: normy określające istotne elementy instytucji kościelnych, których usunięcie spowodowałoby ich deformację (np. nie można dyspensować od obowiązku rezydencji jaki ciąży m.in. na proboszczu); normy określające istotne elementy aktów prawnych (np. nie może podlegać dyspensowaniu norma określając akt zgody, który konstytuuje umowę małżeńską kan. $1057 \mathrm{KPK})^{15}$.

Prawodawca kościelny rozróżnia następujące dyspensy:

1. Odnośnie do zakresu wewnętrznego i zewnętrznego. Zgodnie z ogólną zasadą dyspensa udzielona w zakresie zewnętrznym utrzymuje swoją moc także w zakresie wewnętrznym, chyba, że prawo wyraźnie określa przypadki, w których dyspensa w zakresie wewnętrznym sięga swymi skutkami zakresu zewnętrznego ${ }^{16}$.

2. Wyraźna (expressa) lub milcząca (tacita). Odnośnie do pierwszej, jest udzielana na piśmie, słownie lub znakami jasno wyrażającymi wolę przełożonego. Milcząca wynika logicznie ze słów lub znaków

s. 264; Nie można dyspensować np. od prawa celibatu w tym sensie, by prawo nie obowiązywało przyjmujących święcenia, natomiast można w szczególnych przypadkach udzielić dyspensy od prawa celibatu, aby związanego tym prawem uwolnić od skutków kanonicznych tego prawa.

${ }^{14}$ J. Krukowski, Dyspensa, w: Komentarz do Kodeksu Prawa Kanonicznego, red. J. Krukowski, t. I, Poznań 2003, s. 150.

${ }^{15}$ Tamże, s. 151.

${ }^{16}$ Zob. KPK, kan. 130. 
przełożonego, gdy udziela on nakazu lub zezwolenia wymagającego uprzedniej dyspensy do ich ważnego, czy też godziwego spełnienia, ewentualnie, gdy przełożony wie, że podwładny coś robi wbrew ustawie a nie ingeruje, chociaż powinien i może to uczynić $^{17}$.

3. Można mówić o dyspensie jednorazowej i wielokrotnej, w zależności od tego, czy dotyczy jednego konkretnego i przemijającego aktu, czy też wielu aktów następujących po sobie.

\section{Wladza dyspensowania}

Od obowiązku zachowania ustawy kościelnej może dyspensować sam ustawodawca, jego następca i ci, którzy na mocy prawa uczestniczą we władzy wykonawczej, bądź władza dyspensowania została im wyraźnie mocą prawa lub poprzez delegację udzielona ${ }^{18}$.

Władzę udzielania dyspensy ma przede wszystkim prawodawca, gdyż on jest władny zawiesić skuteczność ustawy w poszczególnym przypadku. $Z$ natury rzeczy władzę dyspensowania posiada także jego następca, bo ma te same uprawnienia co on i tę samą władzę. Dyspensy może udzielić także przełożony prawodawcy, gdyż jego władza jest szersza $^{19}$.

Papież z racji prymatu, na mocy władzy najwyższej, pełnej, bezpośredniej, powszechnej i zwyczajnejej może dyspensować od wszystkich ustaw kościelnych, zarówno powszechnych jak i partykularnych wydanych tak przez niego jak i przez poprzedników, jak też przez niższych przełożonych kościelnych ${ }^{21}$. Historycznie rzecz ujmując,

${ }^{17}$ E. SzTAfrowski, Prawo kanoniczne $w$ dobie odnowy soborowej, t. II, Warszawa 1979, s. 156; Nie wystarczy dyspensa domniemana, która ma miejsce wówczas, gdy podwładny przypuszcza, że przełożony udzieliłby dyspensy, gdy go o to poprosi. W takim wypadku dyspensa nie została faktycznie udzielona i dlatego nie może wywrzeć właściwego sobie skutku.

${ }^{18} \mathrm{KPK}$, kan. 85; Dyspensy mogą udzielać w granicach swej kompetencji ci, którym przysługuje władza wykonawcza, oraz ci, którym przysługuje władza dyspensowania na mocy samego prawa lub prawnej delegacji.

${ }^{19}$ J. GrzYwaCz, Zakres biskupiej władzy dyspensowania, RTK 22 (1975) z. 5, s. 6.

${ }^{20}$ KPK, kan. 331, 333.

${ }^{21}$ W. Aymans, K. Mörsdorf, Kanonisches Recht, t. I, München 2007, s. 157. 
w praktyce różny był zakres władzy dyspensowania wykonywanej przez papieży. Kodeks prawa kanoniczego z 1917 roku przyznał Biskupowi Rzymskiemu właściwie wszelką władzę dyspensowania od prawa powszechnego. Inni przełożeni kościelni mogli dyspensować - nawet w poszczególnych przypadkach - tylko wtedy, gdy taka władza została im wyraźnie przyznana: bezpośrednio lub pośrednio oraz w wypadkach naglących, przy zachowaniu pewnych warunków ${ }^{22}$. Znaczących zmian w dotychczasowej praktyce na tym odcinku dokonano po Soborze Watykańskim II. Wprowadzając w życie uchwały soborowe, papież określił jedynie szczególne wypadki zarezerwowania sobie dyspensy ${ }^{23}$. Biskup Rzymski nawet, gdy chodzi o dyspensowanie od ustaw powszechnych, nie rezerwuje sobie tej władzy w pełnym zakresie, lecz dopuszcza do jej udziału ich przełożonych kościelnych, zastrzegając sobie tylko przypadki o szczególnym znaczeniu ${ }^{24}$. Przy udzielaniu dyspensy papież posługuje się różnymi dykasteriami Kurii Rzymskiej. W zakresie wewnętrznym dyspensy udziela Penitencjaria Apostolska. Są jednak wypadki, kiedy to udzielenie dyspensy zarezerwowane jest Biskupowi Rzymskiemu ${ }^{25}$.

Biskup diecezjalny ${ }^{26}$ może dyspensować wiernych, ilekroć uzna to za słuszne, że będzie to służyć ich dobru, od ustaw dyscyplinarnych powszechnych i partykularnych z wyłączeniem ustaw procesowych

${ }^{22}$ Zob. KPK 1917, kan. 81.

${ }^{23}$ Wstęp do Motu proprio De Episcoporum muneribus, w: PPK, t. I, z. 1, nr 158.

${ }^{24}$ T. Pawluk, Prawo kanoniczne, t. I, s. 265; Por. J. Krukowski, Dyspensa, w: Komentarz do Kodeksu Prawa Kanonicznego, t. I, s. 151.

${ }^{25}$ Zob. KPK, kan. 291, 1698 §2; Tylko Biskup Rzymski udziela m.in. dyspensy od obowiązków wypływających z przyjętych święceń prezbiteratu, czy też od małżeństwa ważnie zawartego, ale niedopełnionego.

${ }^{26}$ Przez biskupa diecezjalnego, mówiąc o aktach władzy wykonawczej, należy rozumieć tego, któremu została powierzona diecezja (zob. kan. 369) oraz zrównanych w prawie z biskupem diecezjalnym, a mianowicie stojących na czele wspólnot wiernych, które prawodawca nazywa prałaturą terytorialną, opactwem terytorialnym, wikariatem apostolskim, prefekturą apostolską i administraturą apostolską erygowaną na stałe (kan. 368, 381 §2 KPK) z wykluczeniem wikariuszy generalnych i biskupich, jeśli nie otrzymali specjalnego zlecenia (kan. $134 \S 3$ KPK). 
i karnych oraz tych, od których dyspensa zastrzeżona jest Stolicy Apostolskiej lub innej władzy ${ }^{27}$.

Zgodnie z obowiązującym Kodeksem prawa kanonicznego Stolicy Apostolskiej wyraźnie zastrzeżone jest dyspensowanie od:

1. prawa celibatu, nawet duchownych, którzy utracili przynależność do stanu duchownego (kan. $291 \mathrm{KPK}$ );

2. zakazu przyjęcia $\mathrm{w}$ szeregi duchowieństwa duchownego, który utracił przynależność do stanu duchownego (kan. 293 KPK);

3. obowiązku biskupa diecezjalnego stawienia się przed Biskupem Rzymu w roku, w którym należy złożyć sprawozdanie ze stanu diecezji (kan. 400 §1 KPK);

4. zakazu przechodzenia $\mathrm{z}$ instytutu zakonnego do instytutu świeckiego lub stowarzyszenia życia apostolskiego oraz odwrotnie (kan. $684 \S 5,730 \mathrm{KPK})$;

5. zakazu opuszczania instytutu zakonnego (kan. 686, 691 § 2 KPK);

6. braku wieku do święceń, jeśli przekracza on jeden rok (kan. 1031 $\S 4 \mathrm{KPK})$;

7. wszystkich nieprawidłowości, jeżeli fakt ich zaistnienia został wprowadzony na forum sądowe (kan. $1047 \S 1 \mathrm{KPK}$ );

8. następujących nieprawidłowości i przeszkód zwykłych do przyjęcia święceń: wypływających z publicznych przestępstw, o których mowa w kan. $1041 \mathrm{nr} 2$ i 328; nieprawidłowości z przestępstwa publicznego, czy też tajnego, o której mowa w kan. $1041 \mathrm{nr} 4^{29}$; przeszkody, o której mowa w kanonie 1042 nr 130;

${ }^{27}$ J. Miras, Poszczególne akty administracyjne. Dyspensy, w: Kodeks prawa kanonicznego - komentarz, red. P. Majer, Kraków 2011, s. 121.

${ }^{28} \mathrm{KPK}$, kan. $1041 \mathrm{nr} 2$ - przestępstwo apostazji, schizmy lub herezji; kan. 1041 nr 3 - usiłowanie zawarcia małżeństwa, nawet tylko cywilnego, bądź sam związany węzłem małżeńskim albo święceniami lub wieczystym publicznym ślubem czystości, bądź też z kobietą związaną ważnym małżeństwem lub takim samym ślubem.

${ }^{29} \mathrm{KPK}$, kan. $1041 \mathrm{nr} 4$ - dobrowolne zabójstwo albo spowodowanie spędzenia płodu, gdy skutek nastąpił, oraz wszyscy pozytywnie współdziałający.

${ }^{30} \mathrm{KPK}$, kan. 1042 nr 1 - mężczyzna żonaty, chyba że jest przeznaczony zgodnie $\mathrm{z}$ prawem do diakonatu stałego. 
9. nieprawidłowości do wykonywania święceń, o których mówią kanony $1041 \mathrm{nr} 3 \mathrm{w}$ wypadkach publicznych oraz kanonu $1041 \mathrm{nr} 4$, w wypadkach zarówno publicznych, jak i tajnych (kan. 1047 §3 $\mathrm{KPK}$;

10. przeszkód małżeńskich wynikających ze święceń, publicznego wieczystego ślubu czystości złożonego w instytucie zakonnym na prawie papieskim oraz małżonkobójstwa (kan. 1078 § KPK);

11. małżeństwa ważnie zawartego ale nie dopełnionego (kan. 1142, $1698 \S 2 \mathrm{KPK})$;

12. od obowiązku odnowienia zgody małżeńskiej przy nadzwyczajnym unieważnieniu małżeństwa, jeżeli nieważność była spowodowana przeszkodą zastrzeżoną Stolicy Apostolskiej lub przeszkodą z prawa Bożego, która już ustała (kan. 1165 §2 KPK);

13. od przysięgi przyrzekającej, jeśli dyspensowanie od niej spowodowałoby szkodę innym, którzy nie zgadzają się na zwolnienie od obowiązku (kan. 1203 KPK).

W pozostałych przypadkach władza dyspensowania przysługuje ordynariuszom. Przez ordynariusza należy rozumieć: biskupa diecezjalnego, zrównanych z nim w prawie oraz mających ogólną i zwyczajną władzę wykonawczą wikariuszy generalnych i biskupich. W odniesieniu do własnego instytutu ordynariuszami są wyżsi przełożeni kleryckich instytutów zakonnych na prawie papieskim oraz stowarzyszeń życia apostolskiego, którym przysługuje przynajmniej zwyczajna władza wykonawcza ${ }^{31}$. Ordynariusz może dyspensować również od wypadków zastrzeżonych Biskupowi Rzymskiemu, jeżeli spełnione są następujące warunki: utrudniony jest dostęp do Stolicy Apostolskiej ${ }^{32}$; grozi wielkie zło, na wskutek zwłoki spowodowanej odwołaniem, zwróceniem się do Stolicy Apostolskiej ${ }^{33}$. Musi to być dyspensa, któ-

${ }^{31}$ Zob. KPK, kan. $134 \S 1$.

${ }^{32}$ Komisja Interpretacyjna, 26 czerwca 1947, AAS 39 (1947) 374; Trudność zachodzi wówczas, gdy nie można byłoby skontaktować się w stosownym czasie obojętnie z jakich przyczyn. Nie ma przy tym obowiązku użycia nadzwyczajnych środków. Trudność nie zachodzi, jeśli ordynariusz może z łatwością kontaktować się ze Stolicą Apostolską przez legata papieskiego.

${ }^{33}$ T. Pawluk, Prawo kanoniczne, t. I, s. 267. 
rej w podobnych warunkach zwykła udzielać Stolica Apostolska przy zachowaniu przepisów Kodeksu ${ }^{34}$.

Od ustaw partykularnych może dyspensować ordynariusz miejsca, a także ilekroć uzna, że domaga się tego dobro wiernych - od ustaw wydanych przez synod plenarny lub prowincjalny oraz konferencje biskupów ${ }^{35}$.

W wielu wypadkach Kodeks prawa kanonicznego wyraźne przyznaje ordynariuszom miejsca władzę dyspensowania od ustaw powszechnych ${ }^{36}$.

Proboszczowie nie mogą dyspensować ani od prawa powszechnego, ani od prawa partykularnego, chyba że taka władza została im udzielona. Na mocy obowiązującego Kodeksu proboszcz może dyspensować:

1. od zachowania dnia świątecznego i pokutnego w poszczególnych przypadkach ${ }^{37}$

2. od przeszkód małżeńskich w niebezpieczeństwie śmierci (kan. 1079 §2 KPK) oraz wszystkich naglących (kan. 1080 §1 KPK);

3. od formy obowiązującej przy zawieraniu małżeństwa, leczy tylko w niebezpieczeństwie śmierci (kan. 1079 §2 KPK);

4. od ślubów prywatnych, jeżeli dyspensa nie narusza praw nabytych przez innych (kan. $1196 \mathrm{nr} 1 \mathrm{KPK}$ );

5. od przysięgi przyrzekającej, jeżeli dyspensa nie przyniesie szkody innym (kan. $1203 \mathrm{KPK}$ ).

Rektorowi seminarium duchownego bądź jego delegatowi przysługuje władza proboszczowska odnośnie dyspensowania tych, którzy

\footnotetext{
${ }^{34}$ Ordynariusz nie może dyspensować, jeżeli Stolica Apostolska w podobnych warunkach nie dyspensuje, albo dyspensuje bardzo rzadko. Np. nie dyspensuje się poza Stolicą Apostolską od przeszkody wypływającej ze świeceń prezbiteratu, nawet w niebezpieczeństwie śmierci (zob. kan. 1079 §1).

${ }^{35}$ W. Aymans, K. Mörsdorf, Kanonisches Recht, t. I, München 2007, s. 279.

${ }^{36}$ Zob. KPK, kan. 1047 §, 1078 §1, 1079 §1, 1080 §1.

${ }^{37}$ Konstytucja Apostolska Paenitemini Pawła VI, AAS 58 (1966) 177-198; To samo może również uczynić przełożony kleryckiego instytutu zakonnego lub stowarzyszenia życia apostolskiego na prawie papieskim w odniesieniu do swoich podwładnych oraz do innych osób przebywających na stałe w domu.
} 
przebywają w seminarium z wyjątkiem spraw małżeńskich (kan. 262 KPK).

Świadek kwalifikowany, prawnie delegowany do asystowania przy zawieraniu małżeństwa oraz kapłan lub diakon asystujący przy zawieraniu małżeństwa wg formy nadzwyczajnej może dyspensować od zachowania formy, oraz przeszkód małżeńskich w niebezpieczeństwie śmierci i w naglącym przypadku (kan. 1079 §2 KPK).

Spowiednik ${ }^{38}$ może dyspensować w zakresie wewnętrznym sakramentalnym i pozasakramentalnym od przeszkód małżeńskich, lecz tylko w niebezpieczeństwie śmierci oraz w wypadkach naglących ${ }^{39}$. W razie nieprawidłowości do wykonywania święceń, gdy przypadek jest naglący i tajny, oraz gdy trudny jest dostęp do ordynariusza lub Penitencjarii (nieprawidłowość płynąca z zabójstwa lub spędzenia płodu) i jednocześnie zagrażałoby niebezpieczeństwo poważnej szkody lub zniesławienia, spowiednik może być pośrednikiem pomiędzy petentem obciążonym nieprawidłowością a podmiotem kompetentnej władzy (nie jest on dawcą dyspensy) ${ }^{40}$.

Przełożony kleryckiego instytutu zakonnego lub stowarzyszenia życia apostolskiego na prawie papieskim może dyspensować podwładnych i osoby przebywające w domu tego instytutu lub stowarzyszenia od ślubów prywatnych, przysięgi przyrzekającej oraz zachowania dnia świątecznego i pokutnego. Władza ta przysługuje przełożonym wyższym, którzy są ordynariuszami ${ }^{41}$.

\section{Przyczyna udzielania dyspensy}

Dyspensa jest pomyślana jako środek zaradczy w szczególnych przypadkach. W zakresie działania dyspensy ustawa - na stałe, lub czasowo - przestaje istnieć w tym konkretnym przypadku. Takie przeznaczenie dyspensy wyznacza poważną rolę przyczynom dyspenso-

${ }^{38}$ J. Krukowski, Dyspensa, w: Komentarz do Kodeksu Prawa Kanonicznego, t. I, s. 156.

${ }^{39}$ W. Góralski, Władza spowiednika, PK 24 (1984) nr 3-4, s. 77-78.

${ }^{40}$ Zob. W. GóRALsKi, Wymogi Kościoła wobec kandydatów do święceń w świetle zmodyfikowanego projektu nowego prawa, Studia Płockie XI (1983) 223-224.

${ }^{41}$ E. Sztafrowski, Podręcznik Prawa Kanonicznego, t. I, Warszawa 1985, s. 206. 
wania, czyli racjom, dla których udziela się dyspensy ${ }^{42}$. Z tego powodu dyspensy od ustawy kościelnej powinno udzielać się na podstawie słusznej i rozumnej przyczyny z uwzględnieniem okoliczności przypadku i ważności ustawy. W przeciwnym razie dyspensa jest niegodziwa, a nawet nieważna, chyba że została udzielona przez samego prawodawcę lub jego przełożonego ${ }^{43}$.

Jeżeli dyspensujący dyspensuje wyłącznie według własnego upodobania bez słusznej przyczyny, wówczas jest niewierny, bo podporządkowuje dobro publiczne prywatnemu dobru. Motywem takiego działania jest wyłącznie wzgląd ludzki44.

Przez przyczynę dyspensowania należy rozumieć motywy, którymi kieruje się dyspensujący zawieszając obowiązywalność ustawy w konkretnym przypadku. Wystarczającą przyczyną do uzyskania dyspensy jest trudność zachowania, lub stan, gdy zachowanie ustawy staje się przeszkodą do osiągnięcia większego dobra ${ }^{45}$. Przyczyna jest słuszna (iusta causa), jeśli jest proporcjonalnie ważna, czyli odpowiednio wielka w stosunku do ustawy, od której ma być udzielona dyspensa. Nie może być sprzeczna z wymogami dobra wspólnego, czyli udzielenie dyspensy powinno przyczyniać się do budowania ładu społecznego w Kościele, w którym szanowane są prawa wszystkich wiernych ${ }^{46}$. Przyczyna jest rozumna, (rationabiliscausa) gdy jest nią dobro duchowe wiernych ${ }^{47}$, bądź konieczność zapobieżenia niebezpieczeństwu poważnej szkody (zob. kan. 87 § KPK). Przyczyna ma być racjonalna, tzn. udzielenie dyspensy ma respektować zachowanie proporcji

\footnotetext{
${ }^{42}$ R. BodAŃSKI, Ważność dyspensy udzielonej bez przyczyny, PK 15 (1972) nr 3-4, S. 81 .

${ }^{43}$ KPK, kan. $90 \S 1$.

${ }^{44}$ J. Grzywacz, Niektóre trudności z udzieleniem dyspens, w: Z zagadnień kultury chrześcijańskiej, Lublin 1973, s. 336.

45 J. Miras, Poszczególne akty administracyjne. Dyspensy, w: Kodeks prawa kanonicznego - komentarz, red. P. Majer, Kraków 2011, s. 123.

${ }^{46}$ Por. J. Krukowski, Dyspensa, w: Komentarz do Kodeksu Prawa Kanonicznego, t. I, s. 157.

${ }^{47}$ Zob. KPK, kan. 90 § 1; Norma ta nakazuje uwzględnić dobro duchowe wiernych, okoliczności przypadku oraz zwrócić uwagę na ważność ustawy, gdyż [Przyczyna powinna być rozpatrywana zgodnie z zasadą słuszności kanonicznej.
} 
między dwoma elementami: okolicznościami i doniosłością ustawy, od której udzielana jest dyspensa. Organ władzy udzielający dyspensy jest zobowiązany najpierw do rozpoznania konkretnych okoliczności $\mathrm{i}$ ich oceny w stosunku do ustawy. Chodzi o to, żeby w stosowaniu prawa każdą sytuację faktyczną potraktować indywidualnie. Kryterium doniosłości ustawy (gravitas legis) polega na ocenie, czy przyczyna motywacyjna dyspensy jest wystarczająca do udzielenia zwolnienia od obowiązku zachowania ustawy ${ }^{48}$.

Ocena przyczyny należy do udzielającego dyspensy. Przy ocenie wystarczalności przyczyny należy wystrzegać się zbytniego rygoryzmu, gdyż nikt nie jest zobowiązany do rzeczy niemożliwych. Zazwyczaj niemożność fizyczna, czy moralna zawiesza obowiązek zachowania prawa. Przyczyna musi być tym większa, im ważniejsze jest prawo, od którego się dyspensuje. Niekiedy sama prośba może być uważana za wystarczającą przyczynę do uzyskania dyspensy ${ }^{49}$.

Ponieważ dyspensa jest łaską, dlatego w zasadzie nikt nie ma ścisłego prawa do jej otrzymania. Konkretne okoliczności mogą być tak złożone, że nawet istnienie wystarczającej przyczyny kanonicznej nie pozwala na udzielenie dyspensy, np. zgorszenie ${ }^{50}$. Jednak w pewnych wypadkach przełożony kościelny musi udzielić dyspensy. Może to mieć miejsce w wypadku istnienia przyczyny kanonicznej, ze względu na uniknięcie zgorszenia, szkody, dla uspokojenia sumienia wiernego $\operatorname{itp}^{51}$.

Dyspensa udzielona przez ustawodawcę lub jego przełożonego bez słusznej i rozumnej przyczyny jest niegodziwa, a jeżeli jest udzielona przez inny podmiot władzy, jest także nieważna ${ }^{52}$. W razie zaistnienia wątpliwości co do tego, czy przyczyna jest wystarczająca, dyspensa będzie udzielona ważnie i godziwie ${ }^{53}$. Mylne przekonanie o istnieniu

${ }^{48}$ Por. J. Krukowski, Dyspensa, w: Komentarz do Kodeksu Prawa Kanonicznego, t. I, s. 157.

${ }^{49}$ Zob. J. GRZYWACZ, Niektóre trudności z udzieleniem dyspens, s. 337.

${ }^{50}$ Tamże.

${ }^{51}$ Zob. B. Höring, Nauka Chrystusa, t. II, Poznań 1962, s. 279.

${ }^{52}$ Zob. V. Pinto, Commento al Codice di Diritto Canonico, Roma 1985, s. 58.

${ }^{53}$ Zob. KPK, kan. 90 § 2. 
przyczyny nie wpływa na ważność dyspensy, jeżeli przyczyna jest wymagana do ważności (kan. 15 §1KPK).

Dyspensę należy tłumaczyć zgodnie z przepisem kanonu $36 \S 1$ KPK. W przypadku wątpliwości, dyspensy odnoszące się do spraw sądowych, naruszające prawa nabyte innych osób, interpretuje się ściśle. Takiej interpretacji podlega także dyspensa udzielona do konkretnego przypadku ${ }^{54}$. Pozostałe dyspensy udzielone dla większej liczby przypadków, o charakterze ogólnym, w razie wątpliwości tłumaczy się szeroko ${ }^{55}$.

Wygaśnięcie dyspensy dokonuje się różnie, w zależności od rodzaju dyspensy. Dyspensa wielokrotna ustaje w ten sposób jak przywilej, a poza tym przez całkowite i pewne wygaśnięcie przyczyny skłaniającej do jej udzielenia. Gdy przyczyna nie wygasła całkowicie, tzn. jeżeli ustała tylko część przyczyn skłaniających lub ich ustanie jest wątpliwe, dyspensa dalej zachowuje swą moc ${ }^{56}$. Ten kto otrzymał dyspensę może się jej zrzec i z niej nie skorzystaćs7.

Nie można odwołać lub cofnąć skutków dyspensy, która osiągnęła swój skutek prawny, a więc z której już skorzystano. Można natomiast odwołać dyspensę udzieloną w formie pośredniej, jeśli wykonawca jeszcze jej nie wykonał. Odwołania, czy przyjęcia zrzeczenia się dyspensy nie może dokonać dyspensujący na podstawie upoważnienia do konkretnego przypadku, gdy jego uprawnienia skończyły się z chwilą udzielenia dyspensy ${ }^{58}$.

${ }^{54}$ Zob. KPK, kan. 92.

${ }^{55}$ L. Chiappetta, Il Codice di Diritto Canonico. Commento giuridico-pastorale, I-II, Napoli 1988, s. 108.

${ }^{56}$ E. Eichmann, Lehrbuch des Kirchenrechts auf Grund des Codex Iuris Canonici, s. 105 .

${ }^{57}$ Zob. E. SzTafrowski, Prawo kanoniczne w okresie odnowy soborowej, t. I, Warszawa 1976, s. 164; Od tej zasady są wyjątki, np. w wypadku dyspensy papieskiej od obowiązków związanych ze święceniami osiąga ona swoją moc z chwilą powiadomienia o reskrypcie papieskim, co powoduje przeniesienie do stanu świeckiego. Nie można wtedy odmówić jej przyjęcia, czy się jej zrzec. Można prosić o ponowne przyjęcie do stanu duchownego.

58 Por. J. Krukowski, Dyspensa, w: Komentarz do Kodeksu Prawa Kanonicznego, t. I, s. 160 . 


\section{Podsumowanie}

Rozdział piąty tytułu czwartego obowiązującego Kodeksu prawa kanonicznego, poświęconego konkretnym aktom administracyjnym, dotyczy dyspens tj. instytucji typowej dla systemu prawa kanonicznego. Instytucja ta służy łagodzeniu surowości ustaw w konkretnym przypadku dla dobra dusz ze względu na szczególne okoliczności osób, miejsca i czasu. Jak wynika z powyższej analizy wszelkie formy udzielania dyspens zawsze suponują wyjątek od ustawy ogólnej, stąd stosunkowo łatwo odróżnić ją od innych aktów administracyjnych. Jak zauważyliśmy ma ona charakter normy korygującej w wypadkach, w których słuszność naturalna domaga się, aby kompetentna władza niejako zawiesiła na moment skuteczność ustawy, która okazuje się zbyt uciążliwa, powodując szkodę lub przeszkadzając w osiągnięciu przez jednostkę większego dobra. Instytucja dyspensy świadczy jednoznacznie o tym, że najwyższym prawem Kościoła jest zbawienie każdego człowieka.

\section{Church dispensation legislation}

The institution of dispensation has evolved since the beginnings of the Church. It has taken various forms, but it has always aimed at loosening the law in a particular case. The Church has changed or moderated its rules and regulations depending on the circumstances. Such loosening of church regulations in particular cases in the primal (original) Church typically took place in order to ensure the valid and decent continuity of what had initially been done unlawfully. In time dispensation was given also before performing some acts, allowing what according the church rules and regulations - had been forbidden.

Each law has as its aim first of all the common good, which is the good of the general public. However, a community consists of individual persons, for whom a particular law may turn out to be too burdensome, causing harm or hindering an individual's achieving of the greater good. Dispensation serves the purpose of dealing with such conflicting situations. It has the capacity of a correcting standard (norm) in cases, in which natural rightness requires a competent au- 
thority to suspend to some extent for an instant the effectiveness of a given church law.

The above article presents the evolution of the institution of dispensation over a span of the Church's history. It discusses the reasons which make a church legislator loosen a law in particular cases; it also discusses the effects of dispensation. 